\title{
The evolution of field neurosurgery in the British Army
}

\author{
Peter H Schurr CBE MA FRCS
}

During the First World War there were no special facilities for the treatment of head injuries until it was realized that early operation and the avoidance of slow and distressing evacuation gave much better results and less infection of the wounds. Hospitals located a few miles from the front were therefore designated for the reception of head-wounded soldiers, and postoperative cases were held there for two or three weeks before being sent on. The principles of what came to be known as neurosurgery were formulated by Harvey Cushing, an American working in Boston. There were very few surgeons with expertise in the treatment of war wounds of the head; however, the need for a thorough exploration and the removal of all bone fragments was slowly appreciated and, when it was possible, primary wound closure soon after injury avoided herniation of brain into the skull defect and scalp wound - a very undesirable condition known as brain fungus. The postoperative mortality was about $50 \%$ but many died before reaching a surgeon. The work of these pioneers was reported in several papers that were a valuable record, ${ }^{1-7}$ though unfortunately not all their experience was remembered twenty years later. There were great advances in technique and equipment in the years between the two World Wars but neurosurgery remained a very small specialty practised by men who had also to care for general cases.

\section{SECOND WORLD WAR}

Hugh Cairns (Figure 1) was a young and enthusiastic surgeon at the London Hospital who had been trained by Cushing in Boston and who had been appointed to the Queen Alexandra Military Hospital, Millbank. In 1938 he was chosen to advise the War Office on the care of head injuries in the forces and to make recommendations for their treatment.

Cairns had by now become the professor of surgery at Oxford, and it was here that he established a 300-bedded Military Hospital for Head Injuries in St Hugh's College. He also created two convalescent homes for their rehabilitation. These units served the Army and Air Force, the Navy having made its own arrangements. St Hugh's Hospital treated some13 000 head-injured patients during the Second

Brook House, High Street, Ufford, Woodbridge, Suffolk IP13 6EQ, UK

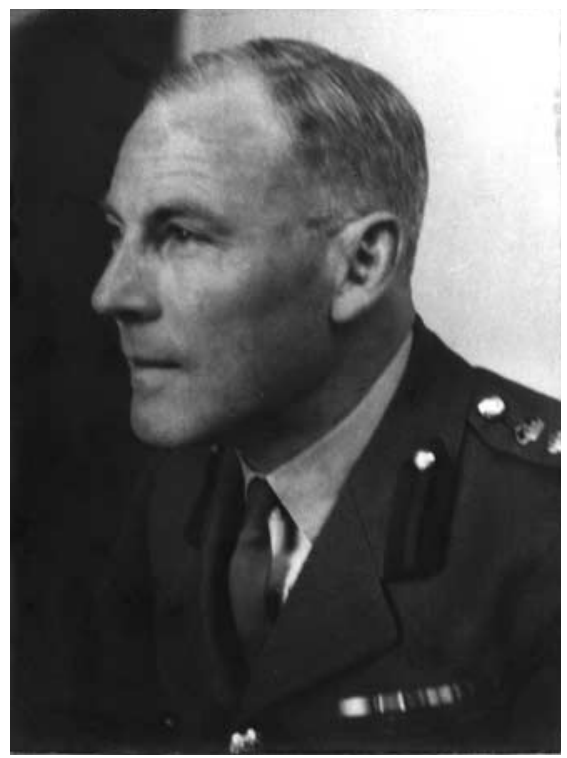

Figure 1 Brigadier Sir Hugh Cairns, KBE, DM, FRCS (Courtesy of the Department of Neurosurgery, The Radcliffe Infirmary, Oxford)

World War and a whole generation of neurosurgeons, neurologists and specialist nurses were trained there.

\section{Mobile neurosurgical units}

In order to provide specialist teams who could treat head injuries within 24-48 hours after wounding, Cairns devised the concept of a mobile neurosurgical unit (MNSU) that could be deployed where the need was greatest. He had a genius for selecting the right person for a particular task and appointed William Henderson, from Leeds, to plan the prototype unit and advise on its establishment and equipment. Thanks to Lord Nuffield and the Silver Thimble Fund, the first of these was fitted out in May 1940.

The plan was for a unit to be attached to a hospital, casualty clearing station (CCS) or field ambulance, and this host unit would provide beds for postoperative patients, extra staff if they were needed, catering, laundry, pathology and radiology services etc. The initial establishment, later modified, consisted of 1 neurosurgeon, 1 neurologist, 1 anaesthetist, 2 general duty Royal Army Medical Corps (RAMC) officers, 2 Queen Alexandra sisters, 4 RAMC orderlies and 2 Royal Army Service Corps drivers. The original vehicle had the appearance of a converted 
ambulance but this was replaced by a 3 -ton and a 15 hundredweight truck, both to be augmented later. There were originally two sets of neurosurgical instruments and one set for general use. Each unit had its own electricity generator, tentage and water supply, as well as other necessary items such as two operating tables, suction apparatus, diathermy and illumination. In fact there was all the equipment needed to carry out at least 200 operations without replacements. ${ }^{8}$

The first MNSU was commanded by Major Henderson and was sent to France in May 1940, where it was attached to a CCS. Soon after its arrival, 233000 personnel were evacuated through Dunkirk, and the unit's nursing sisters went with them. However, the surgeons belonging to the host CCS were deployed elsewhere, and Henderson found himself in charge of 800 wounded soldiers. The unit and its patients were taken prisoner and this MNSU took no further part in the war.

\section{North Africa and Italy}

A new unit was formed in November 1941 and designated No. 1 MNSU. It was sent to North Africa under the command of Peter Ascroft. Italy had attacked the defences of Egypt in September 1940 and their troops were driven back as far as Tunisia with heavy losses. Germany sent General Rommel with considerable numbers of men and matériel and the fighting surged back and forth from the beginning of 1941 until the battle of Alamein in October 1942. The No. 1 MNSU was almost captured in Benghazi. While it was in the desert, 238 operations were carried out, but the Army had not yet learnt how an MNSU should be used or the necessity of separating the head-injured for specialist treatment; only 27 of the soldiers had head wounds.

When the German/Italian advance had reached barely 60 miles from Alexandria, they were posted back to the 15th Scottish Hospital on the banks of the Nile in Cairo. ${ }^{9}$ While the unit was in the desert its potential had not been fulfilled and the whole project almost foundered. Fortunately, however, Major-General Monro (consultant surgeon Middle East Force) and Brigadier McAlpine (consultant neurologist) had faith in Cairns' idea and more units were ordered by the War Office. When the management of head injuries had become properly organized 3804 neurosurgical patients were admitted to this unit, not only from the Western Desert but also from Mesopotamia.

It was not until after the battle of Alamein that the units were used for the purpose for which they had been created. No. $4 \mathrm{MNSU}$, under Kenneth Eden, was commissioned in December 1942 and sent forward with the 8th Army as the Axis forces were driven west. Eden was not only a very

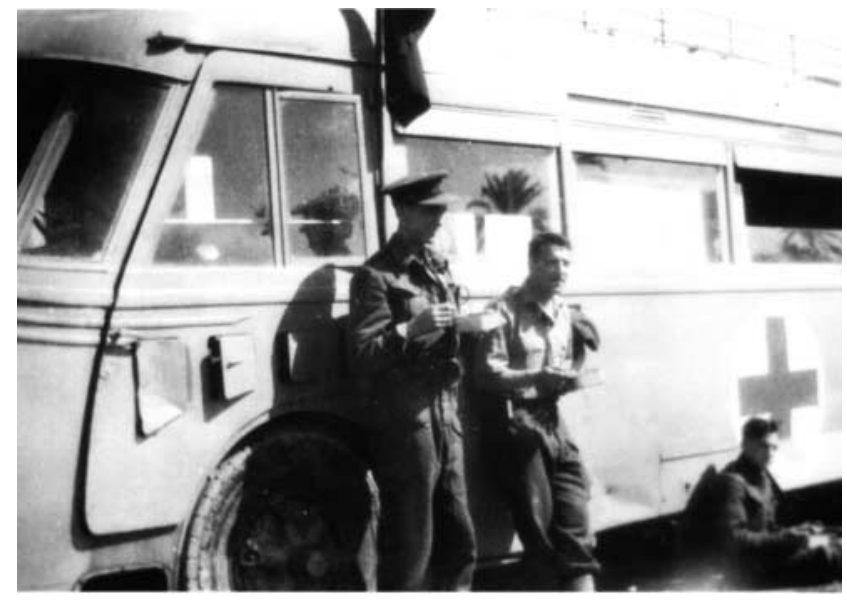

Figure 2 Number 4 MNSU in North Africa. The converted Italian motor coach. Kenneth Eden, J Harbord and Corporal Ottway (Courtesy of the Department of Neurosurgery, The Radcliffe Infirmary, Oxford)

converted an 11-ton Italian motor coach into a mobile operating theatre (Figure 2); it was cramped, but could be packed up and on the move in an hour or two if necessary, and could be brought into use equally rapidly. The coach was attached to two Indian-pattern tents that formed a reception ward, the whole being hosted by a CCS. However, it became apparent that the unit was too far away from the actual fighting and so Eden split it into forward and rear sections. For example, the forward section, attached to a field surgical unit, was at one time in Tunis, while the rear one, with a general hospital, was in Tripoli, about 350 miles behind the lines to the east. The forward section treated all the serious head injuries; others that were less critical were sent back to the rear section or to No. 1 MNSU in Cairo where, at one time, 252 men with head injuries were admitted in 12 days. The system worked efficiently, the patients travelled well and the results were good. It depended on the segregation of head injuries from wounds elsewhere, except in the case of multiple injuries, when collaboration with surgeons in the host unit was easily obtained. Triage of the neurosurgical patients took place in the MNSU and was usually carried out by the neurologist. Even those who were sent from the forward to the rear section were treated within 48-72 hours after being wounded. By these means the incidence of infection, brain abscess, meningitis and brain fungus was reduced from about $25 \%$ to $5 \%$; over $90 \%$ of wounds healed by first intention and it was rare for any further operation to be needed unless it was of a reparative nature. ${ }^{8}$ An important principle is that the first operation on the brain should be the definitive one; second operations are not satisfactory and carry a much greater risk of complications. There is no place for first-aid neurosurgery in the field, except occasionally on account of haemorrhage. ${ }^{10}$ 
No. 4 MNSU followed the 8th Army through Sicily and then up the eastern side of Italy, where they were initially established at Barletta. In North Africa they had taken part in trials of penicillin for wounds of the nervous system, under the guidance of a team consisting of Howard Florey and Hugh Cairns. ${ }^{11}$ It is remarkable that, in the heat of battle, they were able to monitor the levels of penicillin in the blood and cerebrospinal fluid and keep complete records. Because of the extent of this work, conclusions were reached very rapidly. The benefits of penicillin were obvious, particularly in relation to primary healing; however, the principles of treatment and early operation by specialists were not affected, and still stand despite advances in chemotherapy. Tragedy struck when Kenneth Eden developed bulbar polioencephalitis and died in October 1943. The command of the unit passed to a Canadian, H V Slemon, and then to John Gillingham, originally one of the general duty officers.

This (No. 4) unit received many casualties from among the Yugoslav partisans who had been ferried across the Adriatic, 113 of whom arrived with unhealed brain wounds. ${ }^{12}$ Partly for this reason, and because of the advance of the Allies to the Gothic Line and then to the Po Valley, the unit was divided once more. The forward section under John Gillingham ${ }^{13}$ became based at Loreto, just south of Ancona, and then moved up to Rimini; the rear section remaining at Barletta under Campbell Connolly until they also moved forward. The unit had admitted 987 neurosurgical casualties from the battles for the Gothic Line, and the number from the battles for the Po Valley was even greater. The rear section was kept busy with the Yugoslav patients and those sent back from the forward section, 400 miles to the north. In all, No. 4 MNSU admitted 6063 head cases. It is easy to see that the original provision of only one neurosurgeon per MNSU was inadequate. In the case of No. 4, Major Slemon was already trained and able to step in. Their general duty officers had been trained as neurosurgical assistants while at St Hugh's and continued in that role in the field and it was not long before they were themselves capable of independent military neurosurgery. The unit continued to work in Italy until the end of the war.

No. $5 \mathrm{MNSU}$ had been commissioned at the same time as No. 4, with Joe Schorstein in charge. They joined the 1st Army in Tunisia, which formed the left arm of the pincer movement that drove the Axis out of Africa, and then proceeded up the western side of Italy. The 65th General Hospital became their host in Naples and, in May 1944, they treated many head wounds from the battle for Monte Cassino. The unit was divided and was involved in the penicillin trials. They continued working in Italy until after June 1945, and admitted 4600 neurosurgical casualties. ${ }^{8,14}$

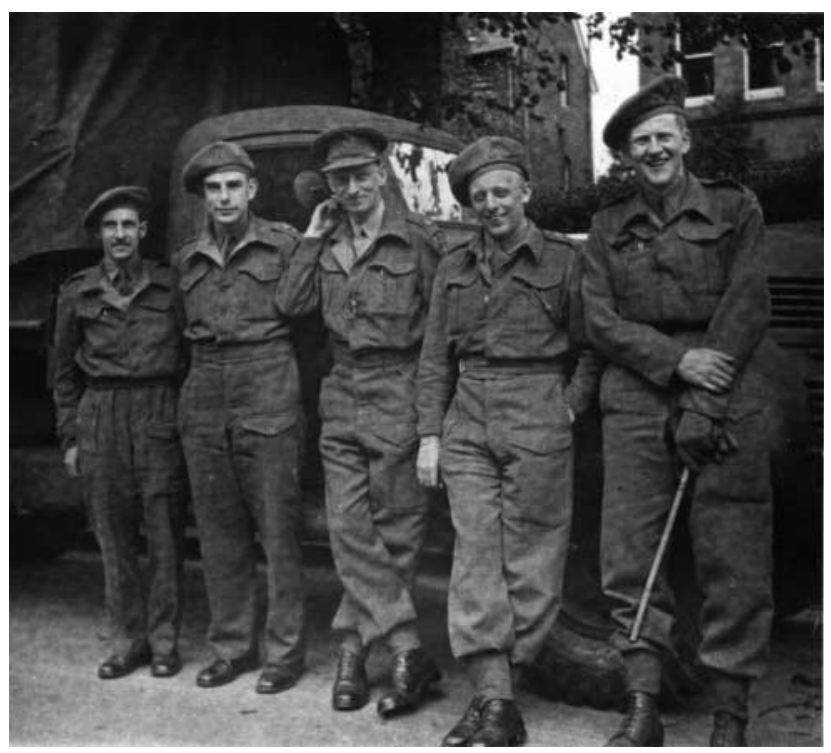

Figure 3 Number 6 MNSU in Oxford before going to France. Messrs Eric Turner, Watt, Jack Small (in command), Spasky and Hartley (Courtesy of the Department of Neurosurgery, The Radcliffe Infirmary, Oxford)

\section{Northern Europe}

Before considering the Asian theatre of war, No. $6 \mathrm{MNSU}$ under the command of Jack Small must be mentioned (Figure 3). This unit, commissioned in June 1944, was with the 21st Army Group in France and Belgium. For a time they too separated into two parts. The lines of evacuation were not comparable with Italy or North Africa, since air transport was readily available to hospitals in Britain. However, the unit admitted 3100 neurosurgical casualties. ${ }^{15}$

\section{India and Asia}

Further contrasts, in climate and topography, were experienced by the MNSUs that worked in India, and Asia. Nos. 2 \& 3 MNSU were commissioned in March and July 1942. They were sent to Secunderabad in central India before moving into Burma, where they had to cope with malaria, dysentery, and scrub typhus; insects, dust, heat and humidity had also to be endured. Because anaesthetized patients cannot control their body temperatures in hot climates, in the absence of any cooling system operations had to be done during the night or early morning unless under a local block. The terrain, especially in Burma, caused immense problems in moving casualties to and from the units. The Chin Hills rose to over 12000 feet (3500 m), the roads were no more than mule tracks and air transport was not often available; the wounded were sometimes reduced to walking very long distances or even being carried on the back of a porter in a head band. 
No. 2 MNSU, under a series of commanders, arrived in Burma late in 1942 when the Japanese had almost achieved their furthest advance, and so had to return to India almost immediately. There followed a period of waiting and training until 1944, when they joined the 14th Army under General Slim in the drive that cleared the enemy out of the country. The conditions were terrible and their equipment was often inadequate; they were constantly on the move and worked in front of No. 3 MNSU. ${ }^{8}$

No. $3 M N S U$, commanded by Richard Johnson, ${ }^{16}$ was sent from Secunderabad to Ranchi, west of Calcutta. It was attached to the 119th Indian General Hospital. In consequence of the Japanese advance, they received many wounded from among those retreating from Burma, none of whom had head injuries. Owing to the absence of any form of hygiene, lack of mepacrine and a shortage of quinine, many of these troops were in a very poor state when they arrived. Bareilly, east of Delhi, was their next location and, at the end of 1943, the unit went to Imphal, in the Assam Hills, near the Burmese border, where the fighting was intense. They were than called back to Comilla, which became, in effect, a neurological hospital for the British and Indian armies. 2045 neurosurgical casualties, including peripheral nerve injuries and those sent back from No. 2, were admitted. The personnel of No. 3 unit were eventually relieved by those of No. $7 \mathrm{MNSU}$, to be mentioned next.

No. $7 \mathrm{MNSU}$ under Eric Turner was sent to India at the end of 1945. Unfortunately the forward and rear parties travelled separately, and when the forward party came to Singapore and was attached to the 69th Indian General Hospital, the rear party with the bulk of their equipment and six Queen Alexandra sisters had not arrived, so they had to borrow nurses from the Indian Hospital who were not neurosurgically trained. At some time in February 1946 the rear party eventually turned up, but No. 7 was soon to be disbanded. ${ }^{17}$

The story of No. $8 \mathrm{MNSU}$ is brief. They were mustered in 1945 but never active. They went out to India and arrived as the Japanese surrendered, so they came straight home again.

\section{RESULTS OF TREATMENT}

The seven MNSUs that were active dealt with well over 20000 patients and $80 \%$ of the soldiers and airmen with head injuries in all theatres of war passed through their hands. ${ }^{8}$ In rough figures, about $90 \%$ of those with scalp wounds and simple skull fractures returned to their units. $70 \%$ of those who were brain wounded were employable in some capacity or other, though hardly any returned to full duty. One has only to compare the mortality and morbidity, including infection rates and rate of primary healing, of the specialist and general surgical teams, to see how the early deployment of neurosurgical skills close to the fighting improved not only the outcome, but also the quality of survival. Eden obtained primary union of scalp wounds in $97 \%$ of cases; the general surgeons treating Alamein patients obtained only 50\%. The respective figures for wounds with an intact dura were $84 \%$ and $12 \%$, and for brain wounds $71 \%$ and $25 \% .{ }^{9}, 10,18$

\section{CONCLUSIONS}

What is the relevance of this experience for today or tomorrow? The main precepts concerned segregation of head injuries, adaptability and early neurosurgical treatment, including the total removal of bone fragments under direct vision, followed by primary wound closure and air evacuation. These requirements still stand. It is worth noting that Cairns emphasized the need to hold specialist equipment in reserve, even in peace time, since it cannot readily be obtained after the outbreak of war; he set about obtaining neurosurgical instruments in 1938.

A veteran neurosurgeon of the Vietnam campaign, Dr Michael Carey of New Orleans, has given permission for the following to be quoted from his forthcoming book on neurosurgery in war:

'So successful was the British MNSU concept that it was adopted by the Canadian Army during World War II and borrowed by Colonel Arnold Meirowski for the American Army in Korea. The American Army neurosurgical detachments and their overall configurations used in Vietnam and Desert Storm and maintained to this day, are direct descendants of the British MNSUs in World War II'.

These words speak for themselves.

The credit for the formation of the MNSUs and for the training and discipline of their staff, lies almost entirely with Brigadier Sir Hugh Cairns, whose paper gives a most comprehensive summary of neurosurgery in the British Army during the Second World War. ${ }^{8}$ Unfortunately the official histories have all but ignored the magnificent contribution made by the MNSUs to the care of the wounded in World War II, but we owe it to Sir Hugh Cairns and the very small band of men and women who served in these units, to continue to provide specialist care, to remember what they had to learn and to see that it does not have to be learnt all over again.

Acknowledgments I am grateful to Dr Michael Carey, Lt Col Peter Stanworth, Major General Norman Kirby, Major General R P Craig, Campbell Connolly and the late Richard Johnson for help and encouragement. 


\section{REFERENCES}

1 Sargent P, Holmes G. The treatment of the cranial injuries of warfare. BMJ 1915;i:537-41

2 Cushing H. A study of a series of wounds involving the brain and its enveloping structures. Br J Surg 1917-18;5:558-684

3 Jefferson G. The physiological pathology of gunshot wounds of the head. BrJ Surg 1919-20;7:262-89

4 Bowlby AA. Interallied surgical conference, 17 May 1917. Arch Med Pharm 1917;68:427-31

5 Wagstaffe WW, Adie WJ. Notes on a series of 161 cases of gunshot wounds of the head treated at No. 7 General Hospital, May to August, 1916. J R Army Med Corps 1918;31:307-15

6 Adie WJ, Wagstaffe WW. Six hundred and fifty six cases of gunshot wounds of the head. Med Res Committee Statistical Rep 1918: 13 June

7 Cushing H. Notes on penetrating wounds of the brain. BMJ 1918;1: 221-8

8 Cairns H. Neurosurgery in the British Army, 1939-1945. Br J Surg 1947; War Surg Suppl. No. 1: 9-26

9 Ascroft PB. Treatment of head wounds due to missiles: analysis of 500 cases. Lancet 1943;ii:211-18
10 Eden KC. Mobile neurosurgery in warfare. Lancet 1943;ii: 689-92

11 Cairns H, Eden KC, Shoreston J. A preliminary report on the treatment of head wounds with penicillin. In Investigation of War Wounds: Penicillin. A Preliminary Report to the War Office and the Medical Research Council on Investigations Concerning the Use of Penicillin. London: War Office Publication AMD7/90D/43

12 Connolly RC. The management of the untreated brain wound. Br J Surg 1947; War Surg Suppl. No. 1: 168-72

13 Gillingham FJ. Neurosurgical experiences in northern Italy. Br J Surg 1947; War Surg Suppl. No. 1: 81-7

14 Schorstein J. Intracranial haematoma in missile wounds. Br J Surg 1947; War Surg Suppl. No. 1: 96-111

15 Small JM, Turner EA, Watt AC. A surgical experience of 1200 cases of penetrating brain wounds in battle, N W Europe, 1944 45. Br J Surg 1947; War Surg Suppl. No. 1: 62-74

16 Johnson RT. Missile wounds of the head in the Burma campaign. Br J Surg 1947; War Surg Suppl. No. 1: 172-7

17 Turner EA. Monthly Reports and Diary No. 7 MNSU. December 1945April 1946

18 Editorial. Surgery of head wounds. BMJ 1944;i:47-8 